Article

\title{
Deciphering cave painting code and ancient celestial map in South East Asia paleolithic cultures dated to $\mathbf{4 0 0 0 0}$ years old
}

Andri Wibowo, ${ }^{1, *}$

Abstract. Currently it was theoritized that cave paintings have meaning more than human and animal interactions. Based on an example from Lascaux cave, a figure of a bull is believed representing Taurus constellation together with the Pleiades. In here this study aims to assess the connections of paleolithic art works in the forms of cave paintings and zoomorphic figures resemble to bovid with possible ancient astronomy and constellation depictions in South East Asia. The study caves were Jeriji Saleh in Kalimantan and Leang Leang and Sumpang Bita caves in Sulawesi where ancient cave paintings and zoomorphic figures date to 40000 years old have been found. The results show that cave paintings in Jeriji Saleh, Leang Leang and Sumpang Bita caves were comparable to the current findings. Those paintings were having bovid like figures with Leang Leang has figure identified as extant Bubalus depressicornis. In Sumpang Bita, this species was depicted in pregnant condition similar to pregnant horse figure in Lascaux cave. Depiction of pregnant figures in cave paintings indicates the use of ancient calendar to determine season based on the animal mating season. Bovid figure in Jeriji Saleh was illustrated in the same posture like auroch bovid in Lascaux cave and this indicates that cave paintings in Jeriji Saleh have been used to visualize Taurus constellation. The postures of bovid paintings in Leang Leang were different and it is interpreted to visualize Capricorn constellation. Another significant similarity between Lascaux and Leang Leang caves can be seen in paintings depicting a shaft scene with the presences of 3 similar figures include dying man, speared bovid and small zoomorphic figures. This concludes that the caves with their wall painting were not merely functioned as media for ancient art works, whereas it has functioned as paleolithic planetarium and this knowledge was globally widespread.
Keywords: ancient, astronomy, cave, constellation, zoomorphic

${ }^{1}$ U. o. Indonesia, West Java, 16424. Indonesia.

*Correspondence email: paleobio2020@gmail.com

\section{Introduction}

Ancient people under paleolithic culture perceived and portrayed the surrounding world in a variety of forms include the ancient art. In Europe, a significant appearance and distribution of paleolithic art works can be dated to approximately 30000 BC and this signifies are considered one of the achievements of the cognitive revolution during Paleolithic period. Some of those arts are categorized as cave arts. The youngest cave art was about 9000 years ago and another one found in caves of Altamira, 
Lascaux and Niaux near the Pyrenees date to $12000-17000$ years ago. The earliest cave paintings were created about 31000 years ago in Chauvet cave (Valladas et al. 2001).

Presences of paleolithic cave art works have also been reported in South East Asian regions (Tan 2014). In mainland Southeast Asia regions, paleolithic cave art works have been reported in Thailand, Cambodia, Laos, Myanmar, Malaysia, Vietnam and Singapore. While in archipelago South East Asia regions in Indonesia, paleolithic cave art works have been reported and found in several remotes places. According to Kosasih (1991), those paleolithic art works were dated back to the epipalaeolithic period and continued through the neolithic period and even in some early metal-using periods. Those art works were distributed widely in Sumatra, Java, Borneo, Sulawesi, lesser Sundas and West Papua. Recent literatures argued that those paleolithic art works were representing human relations to the landscape (Sawatsalee 1998) include hunting activities (Higham and Thosarat 2012) and human connections with wildlife including catfish and elephants. In Indonesia, most paleolithic art works were also believed representing the human-wildlife connections in the forms of hunting. Whereas relatively little attention has been paid to other objects that those art work may represent. In here, this paper tries to assess the connections of those paleolithic art works in the forms of cave painting with possible ancient astronomy and constellation depictions.

\section{Methodology}

The study areas were located in 3 caves that indicate paleolithic occupancies. There were 2 caves located in South Sulawesi and another one was located in East Kalimantan. In South Sulawesi, those caves were located in Leang Leang and Sumpang Bita caves. In East Kalimantan the selected location was Jeriji Saleh cave.



Figure 1. Study areas in 3 caves in Kalimantan and Sulawesi 

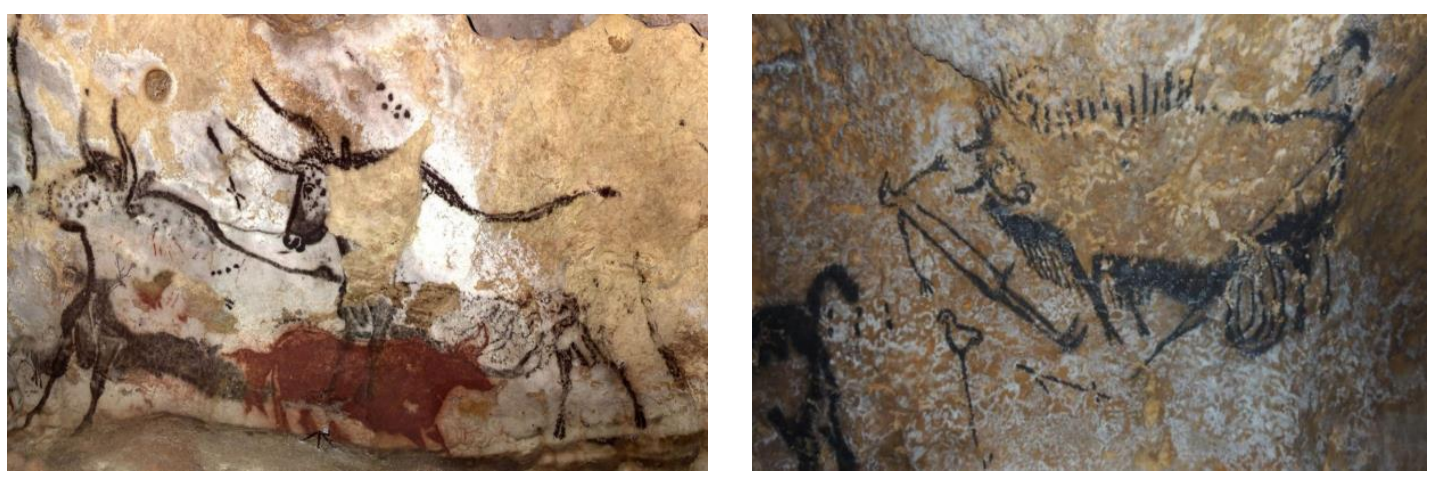

Figure 2. Cave paintings in Lascaux between 18600 and 18900 BP showing auroch bovid in left
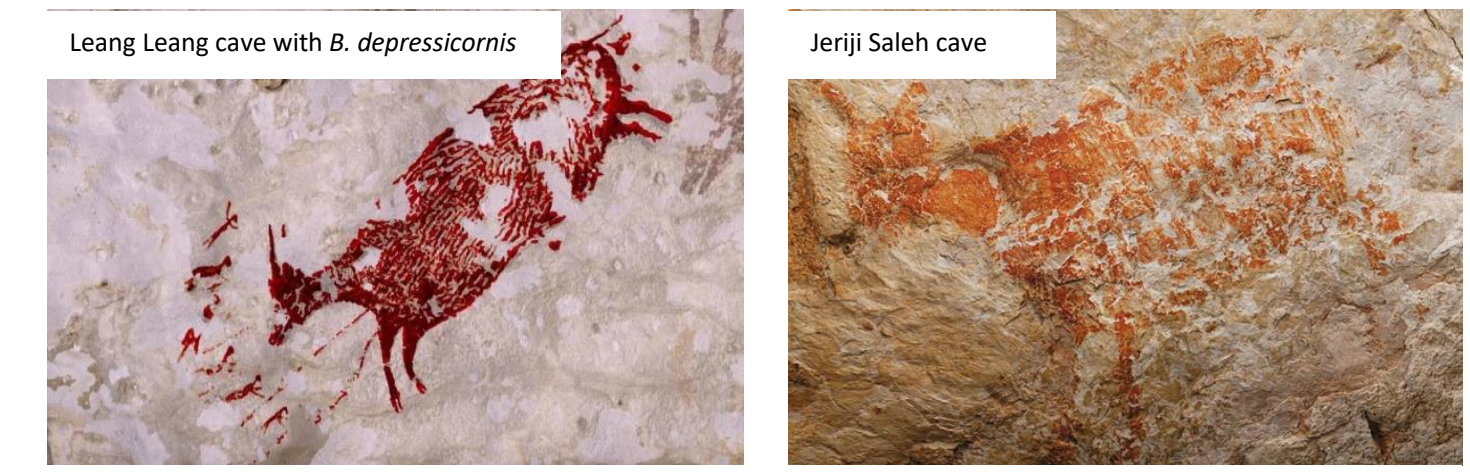

Figure 3. Cave paintings showing anoa bovid B. depressicornis in Leang Leang in Sulawesi $40 \mathrm{Ka}$ (left) and Jeriji Saleh in Kalimantan $40 \mathrm{Ka}$ (right).
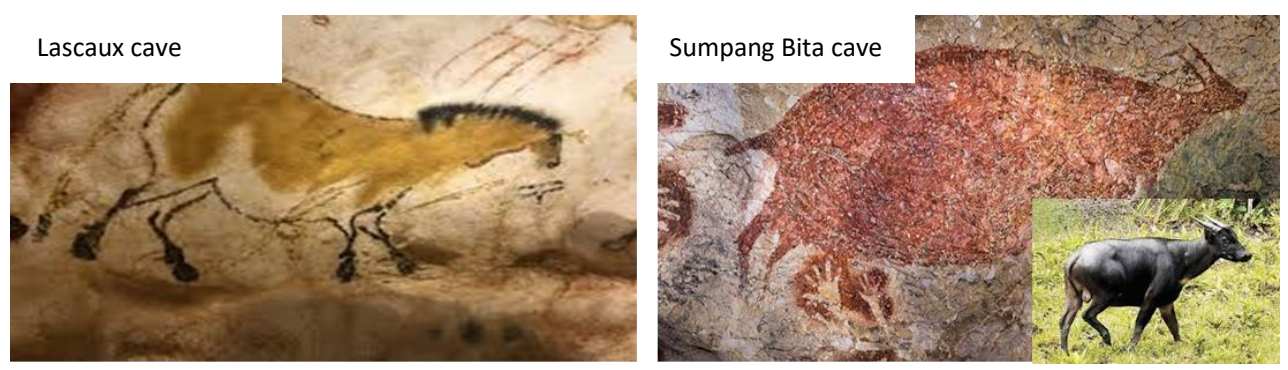

Figure 4. Cave paintings showing pregnant horse in Lascaux (Cotte 2010) and pregnant anoa B. depressicornis in Sumpang Bita with insert photo of an unpregnant individual. Pregnant figures in cave painting indicate season based on the animal mating season. 

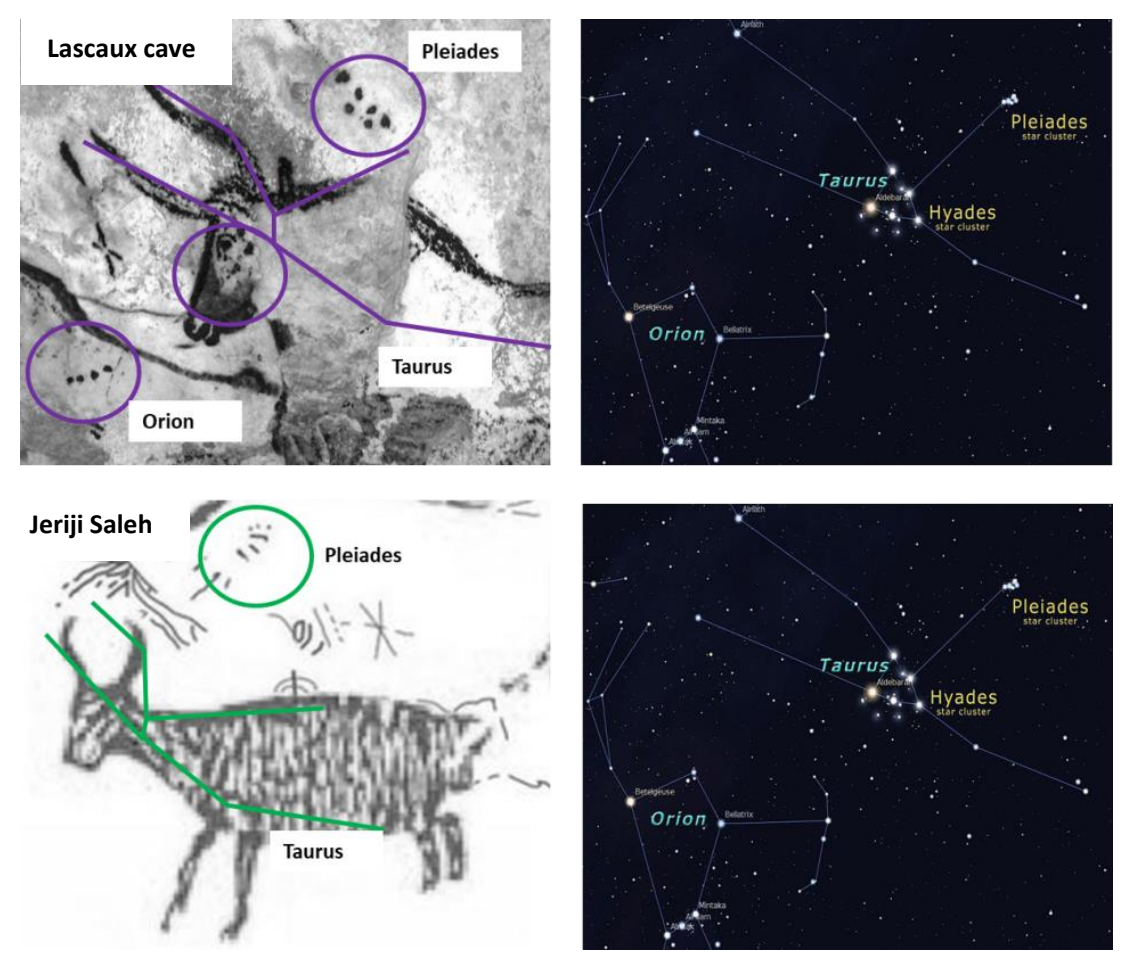

Figure 5. Bovid paintings in Lascaux cave (Congregado 1992; Rappenglück 1997, 2004) and in Jeriji Saleh cave both are visualizing Taurus constellation.

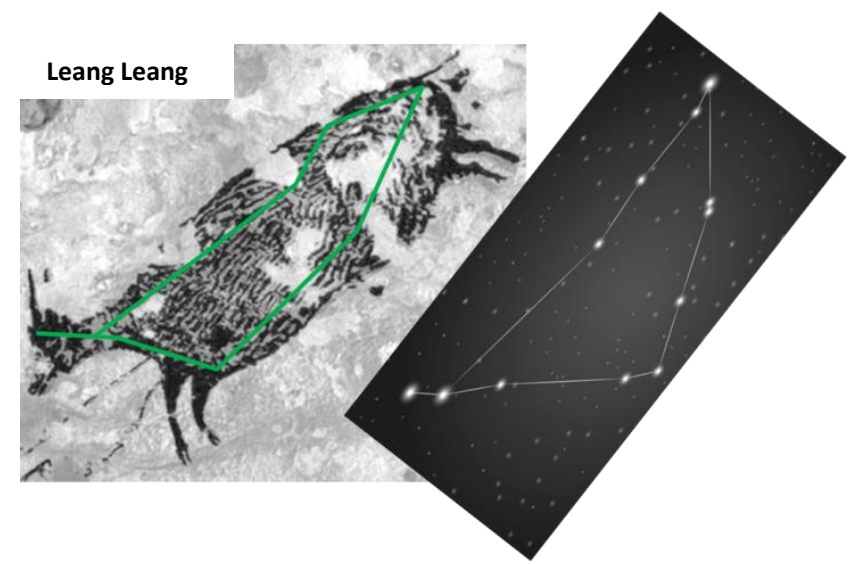

Figure 6. B. depressicornis paintings in Leang Leang cave depicting Capricorn constellation.

\section{Results and Discussion}

\section{Zoomorphic figures}

The first study on cave painting in Leang Leang was done by van Heekeren (1957). It was first theoritized that those cave paintings with zoomorphic figures were representing the presence of Bubalus depressicornis, an endemic mammal or bovid species that still exist until now and living isolated in the rainforest near the cave. Other findings by Akin and Walena (2002) in Tinco and Lawo have confirmed zoomorphic figures representing a horned deer. Whereas close examination reveals that 
those zoomorphic figures mainly in Leang Leang were not represented proportionally since there was a large size individual zoomorphic figure representing anoa that was surrounded by smaller zoomorphic figures in opposite directions. Those zoomorphic figures were not depicted in the right size. Current theory suggest that those smaller zoomorphic figures surrounded anoa were therianthropes, an individual with human-shaped bodies and have the head of a bird and another has a tail.

The 40000 year old cave arts found in Leang Leang and Jeriji Saleh were in comparable to the 17000 year old cave arts found in Lascaux cave due to its similarity mainly in depicted objects mostly horned mammals and bovids whether it can be cows, bulls and deers. According to Valladas et al. (2001), the cave art was made based on the style of fauna depicted. In Lascaux cave (Figure 2), the cave painting included 161 figures represented 58 figurative representations mostly cows and bulls, horses, deer, ibexes and a bison (Martin-Sanchez et al. 2015). The presences of horned mammals in Leang Leang painting were referring to the bovid $B$. depressicornis. that still inhabits the forest nearby. Whereas, a horned mammal alike object in Jeriji Saleh was not matched to neither extinct and extant bovids that living in Kalimantan. This indicates that the depiction of horned animal object as can be seen in Jeriji Saleh perhaps was not intended to represent the existence of wildlife and its interaction with human (Figure 3).

\section{Constellations and paleolithic planetarium}

In contrast to the conservative theory stated that the zoomorphic figures found in cave painting were merely representation of the existence animals. A recent study has hypothesized that those figures were actually representation of astronomical objects. The zoomorphic figures found in Lascaux cave were possibly have astronomical associations and significance included crossed bison, fronting ibex, pregnant horse and associated clusters of dot figures. Those figures were symbolizing natural calendars and even representations of constellations. The fronting ibex in the form of congregation in same-sex herds indicates late summer/early autumn season. While a figure of pregnant horse indicates a summer solstice (Cotte 2010). Correspondingly, a pregnant B. depressicornis as depicted in Sumpang Bita cave may indicate summer season from August to September since this species mating season starts from August and give birth on October (Figure 4).

Another important feature of zoomorphic figures in cave painting is symbolization of complicated constellations. An obvious feature can be seen in in Lascaux cave painting was a cluster of dots above the back of the auroch bovid Bos primigenius resembles the constellation of Pleiades, while the auroch's eye and surrounding dots resemble Aldebaran and the Hyades. This suggests that the auroch figure may be drawn to represent Taurus constellation and indicates ancient astronomy has been 
practiced by cave occupants (Pasztor 2011). To confirm that auroch in Lascaux cave painting was made to visualize Taurus constellation, J'egues-Wolkiewiez (2005) has simulated the sky back to the period when the painting was made and confirmed the presence of Taurus constellation as depicted through auroch painting. The zoomorphic figures represented the constellation in other locations have also been reported by Rappenglück (2004). He reported that 21000 year old drawings in Tęte-du-Lion cave depicts a bison cow with 21 dots arranged in a curved line and a group of 7 dots found on the animals body not far from a single point. It was believed that this picture set represents the Pleiades with the bright star Aldebaran. In corroboration with previous findings, bovid paintings observed in Jeriji Saleh has also portrayed in similar posture with the auroch. Then the Jeriji Saleh figure paintings were assumed to visualize the Taurus constellation. The bovid B. depressicornis observed in wall of Leang Leang was portrayed in different posture than previous bovid figures and was not resemble to Taurus constellation. Then bovid B. depressicornis in Leang Leang was interpreted to visualize Capricorn constellation (Figure 6).

\section{Shaft scene}

Another important drawing in Lascaux cave was known as a shaft scene. This scene depicted as a dying man near the pierced bovid apparently by a spear and seems to be dying. Near the dying man there was another small zoomorphic figure depicted as goose. This scene was also similar to the paintings found in Leang Leang as can be seen a dying man in the front of speared bovid (Figure 7). There was also a small zoomorphic figure near the dying man. A younger similar shaft scene circa 10950 BC can be seen in Göbekli Tepe. According to Sweatman \& Coombs (2018), the shaft scene was representing encounter with the Taurid meteor stream. Since Leang leang painting was older than Lascaux cave then the shaft scene represents the older meteor stream dated back to 40000 years ago.
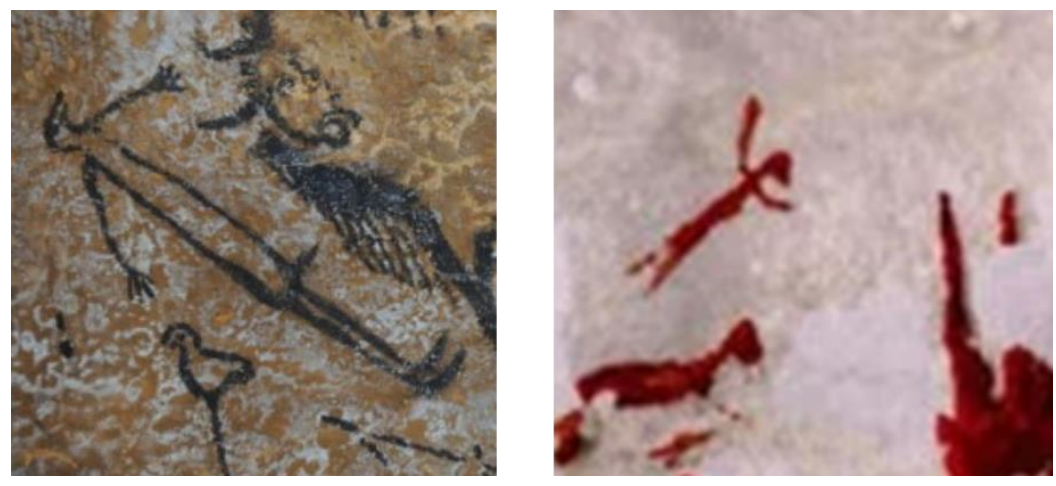

Figure 7. Similarity of shaft scene between Lascaux (left) and Leang Leang (right) 


\section{Conclusion}

Conservative theory still believes that cave paintings merely represent human animal interactions within hunting context. Given findings from the Lascaux cave, cave paintings have beyond interpretations. Likewise, this study is the first that has shed the light mainly in South East Asia that cave occupants already have and developed ancient vast astronomical knowledge.

Author correspondence: Andri Wibowo (paleobio2020@gmail.com)

\section{References}

Congregado LA. 1992. Arte y astronomia: evoluci'on de los dibujos de las constelaciones. PhD thesis.

Cotte M. 2010. Heritage Sites of Astronomy and Archaeoastronomy in the Context of the World Heritage Convention: A Thematic Study.

Duli A \& Walenna EJ. 2002. Makna simbolis beberapa motif goresan pada situs megalitik tinco dan lawo di kabupaten soppeng. Arkeol. Sulawesi Selatan Tenggara 9: 33-39.

Dobrosavljevic-gruji L \& Gruji P. 2017. The language of sky. Publ. Astron. Obs. Belgrade. 96: 407 - 412 Contributed Paper.

Higham C \& Thosarat R. 2012. Early Thailand: From Prehistory to Sukhothai; River Books: Bangkok, Thailand.

J'egues-Wolkiewiez Ch. 2005. Aux racines de l'astronomie, ou l'ordre cach'e d'une oeuvre pal'eolithique (in Les Antiquit'es Nationales) 37: 43.

Kosasih EA. 1991. Rock Art in Indonesia. In Rock Art and Prehistory; Bahn, P., Rosenfeld, A., Eds.; Oxbow Books: Oxford, UK,; 10: 65-77.

Martin-Sanchez P, Miller A, Saiz-Jimenez C. 2015. Lascaux Cave: An Example of Fragile Ecological Balance in Subterranean Environments.

Pasztor E. 2011. Prehistoric astronomers? Ancient knowledge created by modern myth. Journal of Cosmology.

Rappenglück AM. 1997. The Pleiades in the "Salle des Toraux", Grotte de Lascaux. Actas del IV Congreso de la SEAC "Astronomia en la Cultura". Proceedings of the IVth SEAC Meeting "Astronomy and Culture", Jaschek, C. and Barandela, F. (Eds.), 217.

Rappenglück AM. 2004. A Paleolithic Planetarium Underground the Cave of Lascaux Migration \& Diffusion. 5(19): 647. Odyssee-Verlag-Wien.

Sawatsalee S. 1998. Rock Art Painting in Pang Mapha district, Mae Hong Son Province. M.A. Thesis; Arts, Silpakorn University, Bangkok, Thailand.

Sweatman MB \& Coombs A. 2018. Decoding European Palaeolithic art: Extremely ancient knowledge of 
precession of the equinoxes. arXiv: $1806.00046 v 1$.

Tan N. 2014. Rock Art Research in Southeast Asia: A Synthesis. Arts. 3: 73-104.

Valladas H, Clottes J, Geneste J, Garcia M, Maurice A, Cachier H, Tisnérat-Laborde N. 2001. Palaeolithic Paintings: Evolution of Prehistoric Cave Art. Nature. 413.

Van Heekeren HR. 1957. The Stone Age of Indonesia. Nijhoff: The Hague, The Netherlands. 